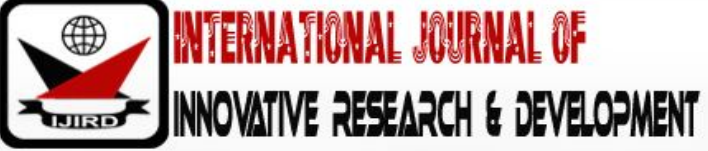

ISSN 2278 - 0211 (Online)

\section{Monetization of the Nigeria Flared Associated Natural Gas Stream in Real-Time Via Conversion to Multiple Utilization Options Using Modular Units}

\author{
Dr. Azunna I.B. Ekejiuba \\ Senior Lecturer, Petroleum Engineering Department, \\ Federal University of Technology Owerri, Owerri, Nigeria
}

\begin{abstract}
:
The previous nine research investigations on this series for the monetization of the associated stranded natural gas in Nigeria, discussed the quantitative conversion of the entire flare stream from a single processing facility to one specificend product such as CNG, LNG, LPG, NGH (GTH), GTW, GTL, NGLs and various petrochemicals including nitrogenous fertilizer (ammonia/ urea). In this concluding publication, the flare stream from a given facility is divided into five fractions and each fraction is used for the production of different specific end products via various skid mounted processing units.

For this study, the $20 \mathrm{MMscfd}$ flow rate flare stream, is composed of 0.492MMscfd impurities,3.8 MMscfd ofnon-methane hydrocarbons and15.708 MM scfd methane. The extracted natural gas liquids (NGLs), containing ethane, propane, butane and natural gasoline ( $\mathrm{C}_{5}+$ hydrocarbons), could be used directly as ethane, commercial propane, commercial butane, propane- butane mixture (LPG), and natural gasoline or as a feedstock for petrochemical/ chemical end products. The purified methane stream is divided into 5 fractions in the ratio $(4: 4: 4: 2: 1.708)$ for electric power generation, synthetic fuel production, nitrogenous fertilizer production, LNG/CNG/ NGH production and petrochemicals/chemicals production respectively, using various technologies available from different licensors for small-scale natural gas modular monetization facilities. Applying the heat of reaction concept for the combustion of methane (when one mole of methane burns, $212.8 \mathrm{kcal}$ of heat are released to the environment) and the relation (one standard cubic foot represents 1.19804 moles or 0.0026412pound moles). For 4MM scfd, it is 4,000,000 x $1.19804=4,792,160$ moles, and the overall heat energy or internal potential chemical energy on the fraction becomes $4,792,160 \times 212.8 \mathrm{k} \mathrm{cal}=1,019,771,648 \mathrm{k} \mathrm{cal}$ or $(1,019,771,648 \times 4.184=$ $4,266,724,575.232 \mathrm{KJ}$ ) while the equivalent conversion to power electricity energy is 14,654.16 kW (approximately $15 \mathrm{MW}$ ). Existing GTL processes convert between 8,500 -12,000 scf of natural gas to about one barrel of synfuel depending on scale of the plant, or between $15 \mathrm{MM}$ Btu to $20 \mathrm{MM}$ Btu, to about one barrel, but the conventional standard is 10,000 scf, with $80 \%$ selectivity for $\mathrm{nC}_{5}+$. Therefore $0.8 \times 4 \mathrm{MMscfd}=3,200,000 \mathrm{scfd}$, which yields: $3,200,000 \mathrm{scf} / 10,000 \mathrm{scf}=320$ barrels, equivalent to $42 \times 320=13,440$ US gallons or $160 \times 320=51,200$ liters.In the Haber-Bosch process balanced equation, the 4 MMscfd fraction, which is equivalent to 4,792,160 moles or 76,674,560grams of methane, reacted with steam to produce $14,376,480$ moles or $28,752,960$ grams of hydrogen. Subsequent reaction of this quantity of hydrogen with nitrogen from the air produced 162,933,440 grams of ammonia which then reacted with carbon dioxide to produce 287,529.600 kg of urea, equivalent of about $5,750.592$ bags of $50 \mathrm{~kg}$ fertilizer per day. Applying their different thermal efficiencies, the available retail heat energy for each of the gas to gas options, using the 2 MMscfd fraction is (CNG 2MMM Btu x $0.93=1,860,000,000 \mathrm{Btu}$ ), (LNG 2MMM Btu x $0.91=1,820,000,000 \mathrm{Btu}$ ), and (NGH 2MMM Btu x $0.85=1,700,000,000 \mathrm{Btu}$ ).

The use of assorted petrochemicals and chemicals plants yields various products from the 1.708 fraction such as plastics of all descriptions, cleaning agents (e.g. soaps and detergents), solvents, dyestuffs, greases waxes, paints, synthetic textiles (e.g. artificial fibers, polyester clothes), synthetic rubbers, epoxy resins, flooring, insulating materials, and products as diverse as aspirin and other drugs, luggage, boats, automobiles, aircraft, adhesives, refrigerants, antifreeze, aerosols, alcohols, explosives, recording discs and tapes etc. This approach is designed to satisfy the various needs of the immediate communities/states for the products, create numerous job opportunities as well as earn very huge revenue from surplus products sales.
\end{abstract}

Keywords: Chemicals, gas monetization, petrochemicals, modular units, nitrogenous fertilizer power electricity generation, synthetic fuel

\section{Introduction}

The produced stream from the crude oil reservoir, produces gas at the surface known as solution gas or associated gas. Stranded natural gas refers to natural gas that is wasted or unused (Shah and Durr,2007) i.e., that has been discovered but is not, or will not be developed due to their location or the economy of getting the natural gas delivered to the market place. Thus, we distinguish between the associated stranded (flared or vented) natural gas and the stranded natural gas 
reserve. Associated stranded natural gas flaring has been a major problem in the petroleum world. It dates back to the very first production well and it is still a common and continuous exercise despite the huge amount of revenue lost as a result of this practice.

In Nigeria, associated stranded natural gas flaring commenced in 1956 with the first successful well drilled at Oloibiri by Shell D' Acry, present day (SPDC) Shell Petroleum Development Company (Ekejiuba,1990). Until 1984, the country flared (ignited) or vented (un-ignited) virtually all the produced associated stranded natural gas while as at 1999, the country still flared well over 70 per cent of the associated stranded natural gas. It reduced from $70 \%$ in 1999 to between 43-52 per cent in 2004, about where, it still remains up-to-date, while the penalty for gas flaring increased to \$3/ M scf in 2010 and currently it officially stands at \$ 3.50/ M scf., since 15 August 2011 (Ofoegbu, 2015). According to Shell Petroleum Development Company (SPDC), on the average, about 1,000 scf of gas is produced in Nigeria with every barrel of oil (Malumfashi, 2008). Therefore, with the organization of petroleum exporting countries (OPEC) quota of 2.5 million barrels of oil production daily, about 2.5 billion scf of associated natural gas is also produced.

\subsection{Study Objectives}

Natural gas monetization options refers to the various processes and ways of converting the energy potentials of natural gas into monetary or utilization value through diverse value-added products, such as direct conversion to electric power ( gas to wire-GTW) or use as a heating fuel for domestic and industrial purposes; conversion to liquids (GTLsynthetic fuels diesel ,gasoline, etc., methanol, dimethylether 'DME') ; conversion to olefins (GTO) and further to polymers (GTP) ; chemical conversion to acetylene, ammonia and urea (synthetic nitrogen fertilizer); production/recovery of natural gas liquids (NGLs) and further conversion of condensed NGLs to petrochemical and chemical raw material/ feedstock; production of liquefied petroleum gas (LPG) and refinery hydrogen; conversion to liquefied natural gas (LNG), compressed natural gas (CNG) and natural gas hydrates (NGH) for easy of transporting the natural gas to the desired destination, figure 1.

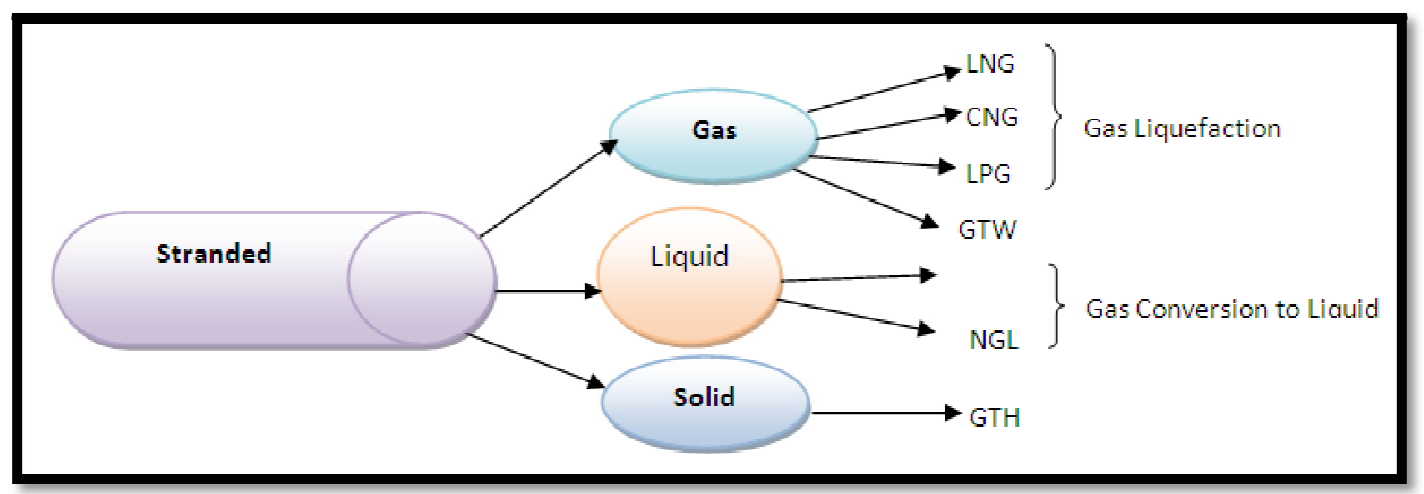

Figure 1: Flared Associated Stranded Natural Gas Monetization Options Source: Adapted From Ekejiuba, 2017a

On monetizing low volume associated gas (Rao, 2016) stated that, there is a truism in chemical processing: size matters. Bigger is better for economies of scale. Consequently, conventional processes fail to address the unique needs of low volume natural gas to be converted to something movable and saleable. His investigation revealed that the majority of, flared natural gas is from pads, producing as little as less than $50 \mathrm{MCF} / \mathrm{D}(50,000$ cubic feet per day) to $200 \mathrm{MCF} / \mathrm{D}$ (200,000 cubic feet per day), that is $0.05 \mathrm{MM}$ cf/ $d$ to $0.2 \mathrm{MM} \mathrm{cf} / \mathrm{d}$. Further, (Layfield, 2016) stated that existing solutions are mature for large-scale applications, but fewer technologies have been used commercially at a small scale. The objectives of this research are to conserve the currently flared associated stranded natural gas by converting it to numerous end-products via small-scale processing applications. Small-Scale facilities provide a means of delivering gas to market requiring as small as $0.2 \mathrm{MMscf} / \mathrm{d}$ and can be transported overland by truck, train or barge.

\subsection{Study Significance}

Presently, Nigeria still flares between 43- 52 per cent of its associated stranded natural gas from about 350-500 flare lines at (flow stations, refining points, terminal operations, offshore platforms etc.), with each burning between 5MM scf to $63 \mathrm{MM}$ scf of associated natural gas daily (i.e. $0.1415 \mathrm{MM} \mathrm{m}^{3} / \mathrm{d}$ to $1.7829 \mathrm{MM} \mathrm{m}^{3} / \mathrm{d}$ ), while about 75 to 80 per cent petroleum products of all descriptions used Nigeria are imported. For instance, over 75 per cent of liquid fuels used in Nigeria are imported, over $80 \%$ of all fertilizer consumed are imported. Nigeria spends over $\$ 10$ billion yearly, to import about $80 \%$ petrochemicals of all descriptions used by various chemical processing industries (Ogunade, 2016), and with the central bank of Nigeria (CBN) exchange rate of N305 to a dollar now, the \$10 billion is equivalent to about N3 trillion. Also, the price of LPG sold in Nigeria is hinged on the Nigerian Liquefied Natural Gas (NLNG) Company international market fundamentals, which has always maintained the retail price for the $12.5 \mathrm{~kg}$ cylinder between $\$ 14$ to $\$ 18$, equivalent of $\$ 500$ to $\$ 5500$ at the exchange rate of $\$ 1=\$ 305$.

Nigeria's annual consumption of LPG has grown from 130,000 metric tons in 2011; 145,000 metric tons in 2012; 250,000 metric tons in 2013; to 500,000 metric tons in 2016 with a potential to hit 2,000,000 metric tons in 2018 (Uwandu, 2017). Meanwhile Nigeria is ranked the lowest in Sub-Saharan Africa in per capita usage of LPG, in consuming 
$1.8 \mathrm{~kg}$ compared with Ghana at $3.0 \mathrm{~kg}$, South Africa $5.5 \mathrm{~kg}$ and Morocco $44 \mathrm{~kg}$. Currently there are about 350 bottling plants while to saturate the market with LPG the country needs about 2000 bottling plants.

Similarly, on electricity supply, the entire power electricity generation for Nigeria, with an estimated population of nearly 190. 3 Million is still below 5,000 megawatts. Going by the 1 megawatt for every thousand conventional rule of the thumb for power generation, for an industrial nation, the Nigerian electricity energy need will be in the range of 190,000 megawatts. Although the governments have been making efforts, especially since 1999 to improve on the situation, their target is to achieve 20,000 megawatts by the year 2020, when the population should have gone beyond 200 million.

Thus, processing the flared associated stranded natural gas in Nigeria, for the various petroleum products will saturate the Nigerian market with the different products thereby alleviating scarcity, as well as drastically reduce their retail prices, generate power electricity and create numerous job opportunities in Nigeria.

Previous research works in this series were aimed at developing customized scaled down processing units (plants) for each particular flare line stream (location), mainly for the production of one specific end product, such as power electricity generation, production of synthetic nitrogen fertilizer, conversion to synthetic liquid fuels (GTL- diesel ,gasoline, etc.), production of liquefied petroleum gas (LPG), production of liquefied natural gas (LNG), conversion of condensed natural gas liquids (NGLs) to petrochemical and chemical raw material/ feedstock figure 2, against the usual conventional approach of a central processing plant with bulk stream collections from various flare lines. This paper investigates the application of more than one of the natural gas small-scale monetization options on an individual flare line (stream), based on the need/ desire of the host community, local government area, state and country, such as combined production of power electricity/ nitrogen fertilizer / GTL-synfuels / petrochemical/ LNG or LPG et cetera, from a single flare line.

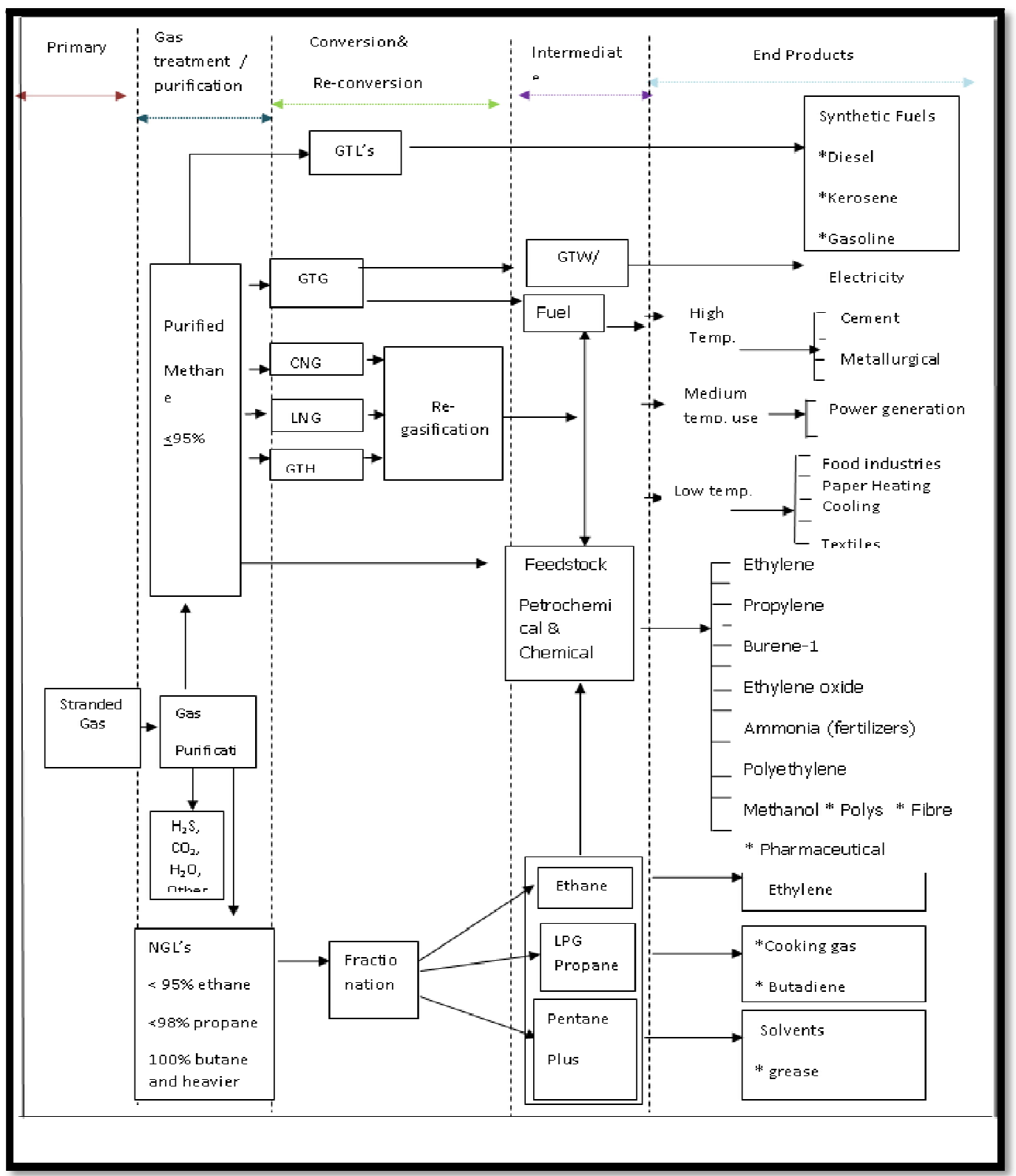

Figure 2: Various Gas Monetization Options

Source: Adapted from Ekejiuba, 2017a 


\section{Background}

Hundreds of different compounds may be present in natural gas in varying amounts, such that, even two wells producing from the same reservoir may produce gases of different composition as the reservoir is depleted, and also each gas stream produced from a well can change composition as the natural gas reservoir is depleted. Thus, there is no one composition or mixture that can be referred to as the natural gas since each stream produced has its own composition (Ikoku, 1980). The major components in most natural gases are paraffin hydrocarbons with smaller amounts- usually only trace, of Olefin hydrocarbons, naphthenic hydrocarbons, mercaptans, and non- hydrocarbon compounds. Primarily natural gas is made up of methane $\left(\mathrm{CH}_{4}\right)$ with minor amounts of ethane $\left(\mathrm{C}_{2} \mathrm{H}_{6}\right)$, propane $\left(\mathrm{C}_{3} \mathrm{H}_{8}\right)$, butanes, pentanes, hexane, heptane, octane and heavier hydrocarbons. While the non-hydrocarbons components (Katz et al.,1959) are: Nitrogen $\left(\mathrm{N}_{2}\right)$, carbon dioxide $\left(\mathrm{CO}_{2}\right)$, Hydrogen sulfide $\left(\mathrm{H}_{2} \mathrm{~S}\right)$, Helium $(\mathrm{He})$, water vapor $\left(\mathrm{H}_{2} \mathrm{O}\right)$, carbonyl sulfide $(\mathrm{COS})$, carbon disulfide $\left(\mathrm{CS}_{2}\right)$, sulfur (S), mercaptans (RSH) e.g. methyl mercaptan and ethyl mercaptan.

Natural gas conditioning and processing (gas treatment) usually termed dehydration and sweetening is basically aimed at producing very high purity methane. The purification processes, removes condensable water vapor, and undesirable compound such as hydrogen sulfide, carbon dioxide, nitrogen as well as recover hydrocarbon vapors (i.e. saleable hydrocarbon liquids) mostly the ethane, propane, butanes and heavier fractions. The above purification process, yields two major products: methane rich stream (almost pure methane 95 to 98\%) and sweetened natural gas liquids stream, mainly ethane $95 \%$ and above, propane $98 \%$ and above, butanes $100 \%$ and pentanes plus $100 \%$, et cetera.

Usually, NGLs are those portions of reservoir gas that are liquefied at the surface in lease separators, field facilities, or gas processing plants. They include but are not limited to ethane, propane, butanes, pentanes, natural gasoline and condensates. NGLs, can comprise 5 to $50 \%$ of the natural gas stream depending on its thermal maturity (Pennsylvania state University, 2017). Also (Salvadar, 2015) stated that the content of NGLs of Natural gas varies widely from essentially none in dry gas to more than $200 \mathrm{bbl}$ (barrels) of NGLs per MM cf (million cubic feet) of gas in rich wet gas (8.4 gallon/ 1000 cubic feet).

\subsection{Ranges of the Small-Scale Natural Gas (methane) Monetization Process Applications}

The design sizes for the various small-scale natural gas monetization options can be customized to process the available quantity of gas required to yield specific quantity of desired end-product.

- For electric power generation, the actual amount of power electricity obtainable will depend on several factors including the type of gas- turbine, the efficiency or heat rate of the generator (or power plant) and the calorific value of gas (heat content of the fuel) etc. Typical operational examples show that, between 9,000 Scf/hr to $14,500 \mathrm{Scf} / \mathrm{hr}(254.7-410.35 \mathrm{~m} 3 / \mathrm{hr}$ ) of sweetened natural gas (methane) is burnt to generate one kilowatt hour of electricity. But the common standard is that, it takes about 1,000 cubic feet $(0.01003 \mathrm{Mcf}$ or $0.01011 \mathrm{Mcf})$ of natural gas to make $1 \mathrm{kwh}$ including power plant inefficiency (michaelbluejay.com; naturalgas.org.; energy information administration). The existing possible conversion process techniques include the distributed generation i.e. micro-turbines, industrial gas-fired turbines, natural gas fuel cells; the centralized gas turbines and the aero-derivative units.

- For synthetic fuels production, the GTL technologies available from different licensors differ in process configuration, thermal efficiencies and capital costs, but overall the size of GTL plants vary from small (5 to 15, $000 \mathrm{bpd}$ ) to large (>50,000 bpd). The standard conversion table for gas to liquid is $100 \mathrm{MMscfd}$ equal 10,000bpd of Fischer-Tropsch Liquid, thus the GTL processes in operation converts 10,000 cubic feet ( $0.010 \mathrm{MM}$ cf) or (286 $\mathrm{m}^{3}$ ) of gas into slightly more than I barrel $\left(0.16 \mathrm{~m}^{3}\right)$ of liquid synthetic fuels, i.e. 42 US gallons or 160 liters. Although this can vary, depending on the scale of the GTL plant, the range for gas consumption is between 8,500 to 12,000 cubic feet/ barrel. On the other hand, some GTL designs converts every 15MM Btu (15 million Btu) 20MM Btu into one barrel of clean- burning, synthetic fuel. The 2003 demonstration plant at Oklahoma converts $4 \mathrm{MMcf}(114,600 \mathrm{~m} 3)$ per day of natural gas to $400 \mathrm{bpd}(64 \mathrm{~m} 3 / \mathrm{d})$ of sulfur-free diesel and naphtha. Typical output yield for a GTL process consists of about 70\% ultra-clean diesel fuel, 25\% naphtha and a few percent LPG's, Lubes and waxes.

- A petrochemical is any chemical compound obtained or derived from petroleum or natural gas hydrocarbons and utilized in chemical market. It includes a whole range of aliphatic, aromatic and naphthenic organic chemicals and inorganic materials such as sulfur and ammonia. All petrochemicals are derived from three sources:

$>$ Reforming natural gas (methane) to synthesis gas (syngas): carbon monoxide / Hydrogen $\left(\mathrm{CO} / \mathrm{H}_{2}\right)$.

$>$ Olefins from pyrolysis of ethane, propane-butane (LPG) or distillates.

$>$ Aromatics from catalytic reforming.

The three main source of petrochemical lead to products which are marketable items in their own right, as well as raw materials for a great many other petrochemicals used both as intermediates and as finished products. The plant sizes for petrochemicals/ chemicals production vary extensively depending on the desired product.

(iv) For the production of fertilizer using the Haber-Bosch process, the obtainable quantity is based on the balanced equation 1 (Sherman and Sherman,1999), 1 mole of nitrogen and 3 moles ofhydrogen react to produce 2 moles of ammonia (ratio: $1 \mathrm{~N}_{2}: 3 \mathrm{H}_{2}: 2 \mathrm{NH}_{3}$ ). The atomic mass of nitrogen is 14.0, while the atomic mass of hydrogen is 1.0. Thus, 1 mole of nitrogen has a mass of 28.0 grams; 1 mole of hydrogen a mass of 2.0 grams, and 1 mole of ammonia a mass of 17.0 grams. 
$\mathrm{N}_{2}+3 \mathrm{H}_{2} \longleftrightarrow 2 \mathrm{NH}_{3}$

1 mole 3 moles 2 moles

28.0 gram 6.0 grams 34.0 grams

Equation 2, is the balanced reaction for hydrogen production from methane:

$\mathrm{CH}_{4}(\mathrm{~g})+\mathrm{H}_{2} \mathrm{O}(\mathrm{g}) \longleftrightarrow \mathrm{CO}(\mathrm{g})+3 \mathrm{H}_{2}(\mathrm{~g})$

1 mole 1 mole 1 mole 3 moles

Applying the conversion from standard cubic feet (scf) to moles factor, ( 1 scf $=1.19804$ moles), implies that every one standard cubic feet of methane will yield 1.19804 moles of methane.

\section{Process Model Material}

Table 1 shows the typical representative composition of the flared associated stranded natural gas stream in Nigeria, obtained from statistical analysis of 36 flare streams, selected from 150 flare line data samples (Ekejiuba, 2017a). And table 2 contains the average operational parameters of the Nigeria flare gas stream.

\begin{tabular}{|c|c|}
\hline Component & Mole\% \\
\hline Methane & 78.5375 \\
\hline Ethane & 7.7880 \\
\hline Propane & 5.9625 \\
\hline Butane & 1.4842 \\
\hline n-Butane & 1.8882 \\
\hline i-Pentane & 0.6964 \\
\hline n-Pentane & 0.4982 \\
\hline Hexane Plus & 0.7550 \\
\hline Nitrogen & 0.1729 \\
\hline Carbon dioxide & 2.0105 \\
\hline Other Undesirables & 0.2066 \\
\hline Total & 100.0000 \\
\hline
\end{tabular}

Table 1: Typical Representative Composition of Nigerian Flare Gas Steam

\begin{tabular}{|c|c|c|}
\hline Other Parameters & Range & Value for the Study \\
\hline Gas Gravity (Air =1) & 0.607 to 0.996 & 0.755 \\
\hline Flowrate MMscfd & 5 to 63 & 20 \\
\hline Pressure Psig & 7 to 75 & 10 \\
\hline Pressure Psia & 21.7 to 89.7 & 25 \\
\hline Temperature $^{0} \mathrm{~F}$ & 60 to 115 & 80 \\
\hline Base Temperature During & & $60^{\circ} \mathrm{F}$ \\
\hline Analysis & & \\
\hline Base Pressure During Analysis & & $14.7 \mathrm{psia}$ \\
\hline
\end{tabular}

Table 2: Typical Representative Conditions of Nigerian Flare Gas Steam

Figure 3 depicts the prevailing situations in most wellhead and gas process facilities (flow stations, refineries, off shores and terminal operations).

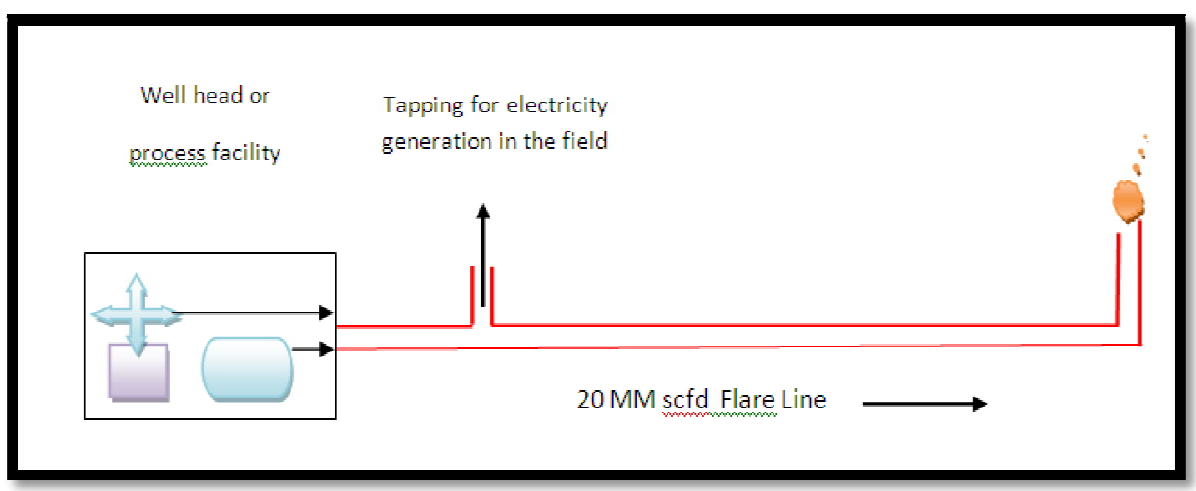

Figure 3: Existing Approach

\section{Model Application and Results}

This study considered the integrated approach for the monetization of the associated stranded natural gas from any particular flare line. The entire flare stream with the typical composition $\mathrm{C}_{1}(78.5 \%), \mathrm{C}_{2}+(21.5 \%)$ and flow rate of 20 
MM scfd, tables 1 and 2 is processed to recover elemental nitrogen, carbon dioxide, water as well as separate individual NGLs from the natural gas (methane) table 3. Subsequently the methane stream is divided into five fractions, each designed to yield one specific end product figure 4.

\begin{tabular}{|c|c|c|c|}
\hline Component & Mole \% & $\begin{array}{c}\text { Fractional } \\
\text { Composition }\end{array}$ & $\begin{array}{c}\text { Daily Production, Scf, } \\
\text { (for 20MM scfd stream) }\end{array}$ \\
\hline Methane & 78.5375 & 0.7854 & $15,708,000$ \\
\hline Ethane & 7.7880 & 0.0779 & $1,558,000$ \\
\hline Propane & 5.9625 & 0.0596 & $1,192,000$ \\
\hline i-butane & 1.4842 & 0.0148 & 296,000 \\
\hline n-butane & 1.8882 & 0.0189 & 378,000 \\
\hline i - Pentane & 0.6964 & 0.0070 & 140,000 \\
\hline n - Pentane & 0.4982 & 0.0050 & 100,000 \\
\hline Hexane and heavier & 0.7550 & 0.0075 & 150,000 \\
\hline Nitrogen & 0.1729 & 0.0017 & 34,000 \\
\hline Carbon Oxide & 2.0105 & 0.0201 & 402,000 \\
\hline Hydrogen Sulfide & 0.00 & 0.00 & 0.00 \\
\hline Water vapor & 0.2066 & 0.0021 & 42,000 \\
\hline Total & 100.00 & 1.0000 & $20,000,000$ \\
\hline
\end{tabular}

Table 3: Individual Ngls Separated from the Natural Gas (Methane)For a Typical Nigerian Flare Gas Stream

NB: Production from Different Wells Will Have Different Compositional Analyses and to Convert It to Barrels, Gallons, Cubic Meters or Liters, Requires the Appropriate Conversion Factor)

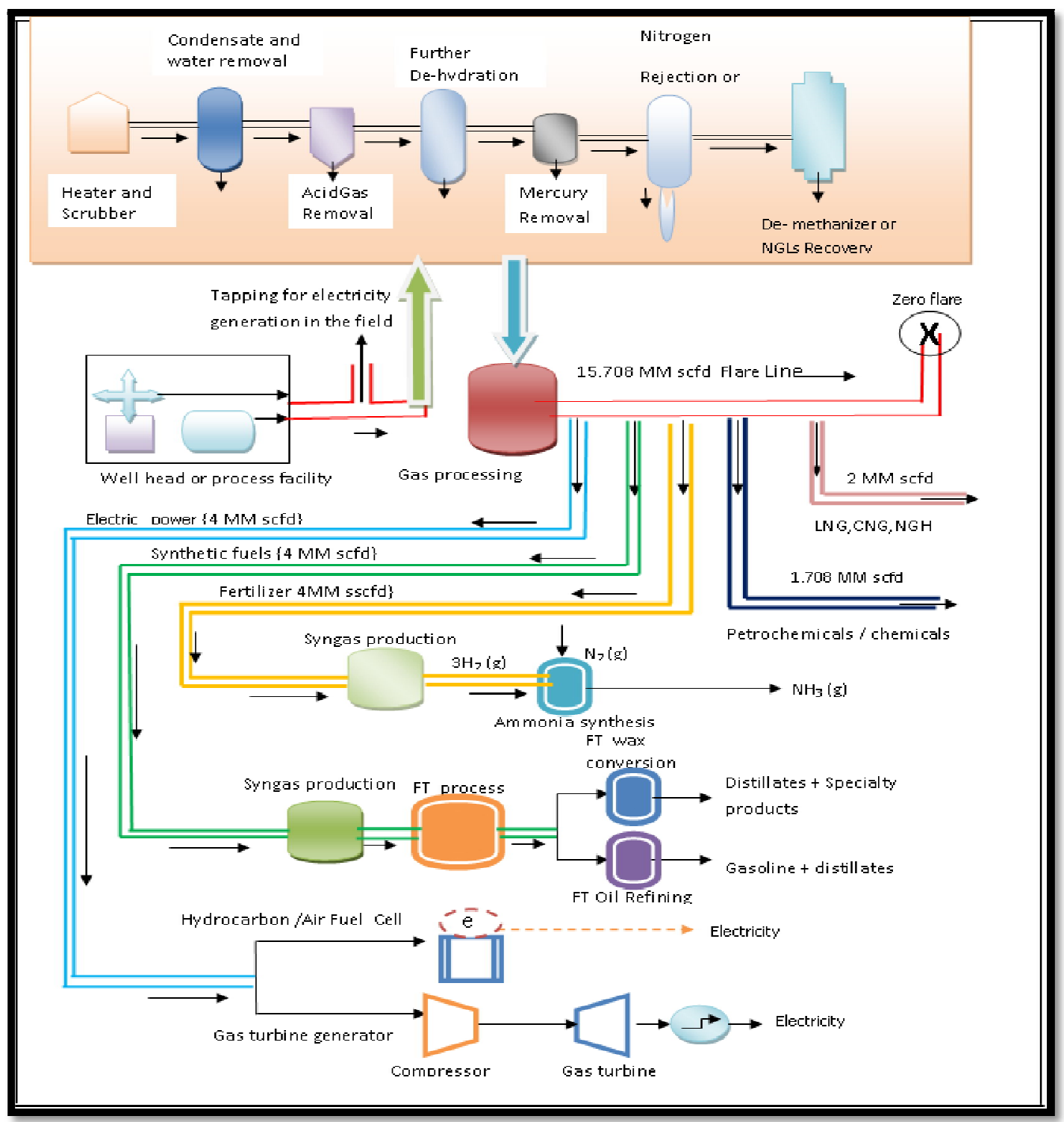

Figure 4: Proposed Integrated Associated Stranded Natural Gas Monetization Layout 
4.1. Model Results for the Real-Time LPG/ NGLs Production from the Typical Nigerian Flare Gas Stream

Natural gas conditioning treatment (processing) usually termed dehydration and sweetening involves:

- Dehydration i.e. conditioning the natural gas stream to remove condensable water vapor, free water and solids impurities which under certain conditions might cause hydrate formation.

- Sweetening i.e. processing the natural gas stream to remove undesirable compounds (acid gases), such as hydrogen sulfide, carbon dioxide and nitrogen, which in presence of water, might form acids or acidic solution that are toxic, poisonous and corrosive.

- Natural gas liquids (NGLs) recovery i.e. processing the natural gas stream to remove condensable hydrocarbons i.e. saleable liquid hydrocarbons, figure 5.

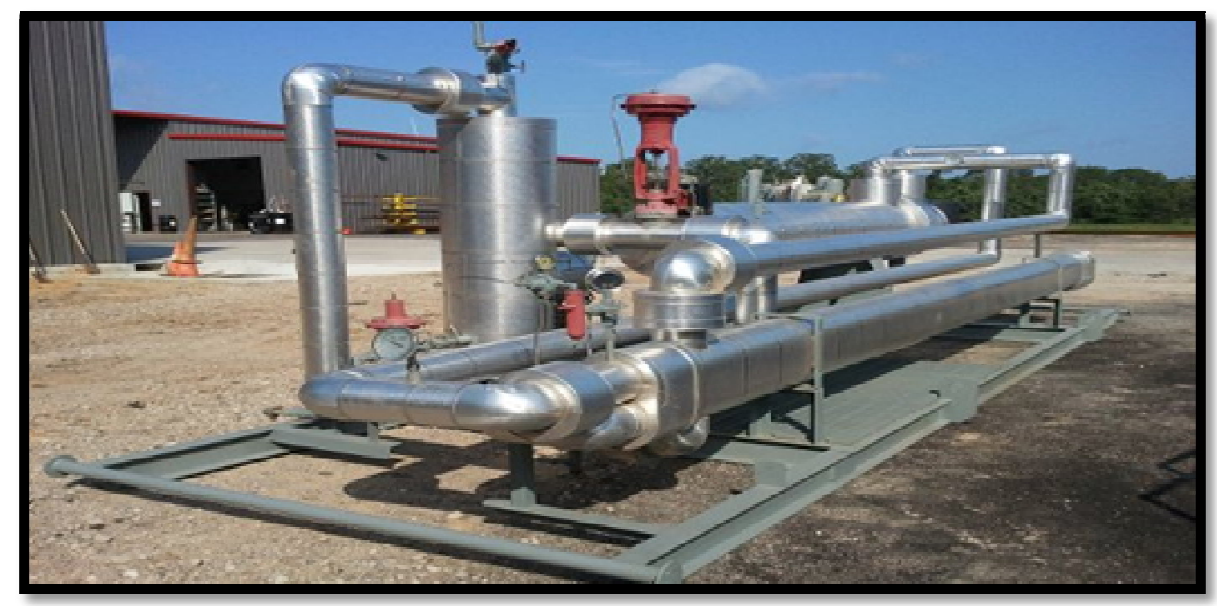

Figure 5: Anngls Recovery Unit

Source: Adapted from NGL Recovery: Process and Equipment-Croft Production System

The above treatments yield two main products:

- The methane rich stream i.e. very high purity methane (95 to 98\%) polluted with minor ethane and propane.

- The natural gas liquids stream i.e. saleable liquid hydrocarbons, mostly ethane plus components.

The extracted natural gas liquids (NGLs), containing ethane, propane, butane and natural gasoline ( $\mathrm{C}_{5}+$ hydrocarbons), can be used.

- Directly as ethane, commercial propane, commercial butane, propane- butane mixture (LPG), and natural gasoline or

- As a feedstock for petrochemical/ chemical end products, via conversion of alkanes to alkenes reactions, such as the conversion of ethane to ethene (ethylene):

$\mathrm{CH}_{3} \mathrm{CH}_{3} \longrightarrow \mathrm{CH}_{2}=\mathrm{CH}_{2}+\mathrm{H}_{2}$

following:

On the other hand, the dry treated natural gas i.e. conditioned methane rich stream could be used for any of the

Directly as fuel: residential, industrial and power generation (electricity)

- As a residential fuel, it is burned in furnaces, water heaters, cooking stoves; clothes dryers, refrigeration or space cooling and air conditioning.

- As an industrial fuel, it is burned in kilns (special furnaces) used to bake bricks, and ceramic tiles and to produce cement.

- Injected into transmission lines for supply to independent power plants (IPP) for electrical power generation; Gas-to-wire (GTW), as source of electrical and heat energy for iron smelting in iron and steel industry, Aluminum industry, glass and food processing industry.

Directly as raw material for creating petrochemicals (i.e. as a precursor of a wide variety of compounds via synthesis gas) such as methanol, formaldehyde, ammonia and urea fertilizers, oxoalcohols, chloromethanes, detergents, pharmaceuticals, plastics etc.

- Either liquefied to obtain liquefied natural gas (LNG) or converted to hydrates using Gas-to-hydrate (GTH) technology for export and later regasified for use as either fuel or raw material for creating petrochemicals.

- Directly compressed to yield Compressed Natural Gas (CNG) for vehicles etc.

- As a liquid fuel energy source i.e., conversion to liquid using Gas to liquid (GTL) plants, to yield fuel oil, diesel, gasoline, liquefied petroleum gas (LPG) etc. 


\subsection{Model for the Real-Time Electric Power Generation Using 4mmscfd Fraction of the Methane}

\subsubsection{Overview of the Potential Chemical Energy on $4 \mathrm{mmscfd}$ Fraction of the Flare Stream}

An alkane undergoes combustion when it reacts with oxygen to produce carbon dioxide, water, and energy (Timberlake,2006).

Alkane $+\mathrm{O}_{2} \longrightarrow \mathrm{CO}_{2}+\mathrm{H}_{2} \mathrm{O}+$ energy

The oxidation of alkanes (saturated hydrocarbons) by $\mathrm{O}_{2}$ to give carbon dioxide and water is by far their most economically important reaction, and is the basis for their use as energy sources for heat nnatural gas/ liquefied natural gas (LNG), liquefied petroleum gas (LPG), and fuel oil) and power (gasoline, diesel fuel, and aviation fuel\} (Brown, et al 2005). Standard heat of combustion is the heat released when one mole of a substance in its standard state (gas, liquid, solid) is oxidized completely to carbon dioxide and water, and is given the symbol $\Delta \mathrm{H}^{\circ}$.

The equations for the combustion of methane $\left(\mathrm{CH}_{4}\right)$ and propane $\left(\mathrm{C}_{3} \mathrm{H}_{8}\right)$ are:

$$
\begin{aligned}
& \mathrm{CH}_{4}+2 \mathrm{O}_{2} \longrightarrow \mathrm{CO}_{2}+2 \mathrm{H}_{2} \mathrm{O} \text { +heat energy: } \Delta \mathrm{H}^{0}=-890.4 \mathrm{KJ}(-212.8 \mathrm{k} \mathrm{cal}) / \mathrm{mol} \\
& \mathrm{C}_{3} \mathrm{H}_{8}+5 \mathrm{O}_{2} \longrightarrow 3 \mathrm{CO}_{2}+4 \mathrm{H}_{2} \mathrm{O}+\text { heat energy } \Delta \mathrm{H}^{0}=2220 \mathrm{KJ}(-530.6 \mathrm{kcal}) / \mathrm{mol}
\end{aligned}
$$

The reaction is exothermic i.e. when I mole of methane burns, $212.8 \mathrm{kcal}$ of heat are released to the environment. One standard cubic foot represents 1.19804 moles (0.0026412-pound moles) (en.wikipedia), and 4MM scfd, will yield $4,000,000 \times 1.19804=4,792,160$ moles.

Therefore, the total heat released from this fraction of stream becomes $(4,792,160 \times 212.8 \mathrm{k} \mathrm{cal}=1,019,771,648 \mathrm{k} \mathrm{cal}$.) or $(1,019,771,648 \times 4.184=4,266,724,575.232 \mathrm{KJ})$, since $1 \mathrm{cal}=4.184$ joules.

On the other hand, Fuel heat content vary depending on the content of inorganic compounds. The heating value of natural gas usually varies from $700 \mathrm{Btu} / \mathrm{Scf}$ to 1,600 Btu/ Scf. But the gas conversion tables assume calorific value $=1,000$ Btu/ Scf.

Therefore, 4,000,000 Scf/ d x 1,000 Btu/Scf $=4,000,000,000 \mathrm{Btu} / \mathrm{d}$ and dividing this by 24 hours yields $166,666,666.6667 \mathrm{Btu} / \mathrm{hr}$.

The Conventional relation for the chemical energy of fuel is:

Chemical energy of fuel=Total fuel used (Scf/ hr)x higher heating value (HHV)(Btu/ Scf)

\subsubsection{Results of the Evaluation for the Power Electric from 4mmscfd Fraction of the Flare Stream}

Generally, on the other hand the amount of electricity power available from a fixed quantity of feed gas depends on several factors including:

- The types of gas- turbine generator (GTG) and it's mode of operation (i.e. Whether OCGT, CCGT or others).

- The calorific valves of gas (heat content of the fuel), i.e. Chemical energy of fuel

- Efficiency or heat rate of the generator (or power plant).

The power plant efficiencies (heat rates) is the performance parameter for the plant. It varies by types of generators, power plant emission controls, and other factors and reflects the total energy input supplied to the generator divided by the electrical energy output.

Heat Rate $=$ Thermal Energy IN/ Electrical Energy OUT

Since the energy input to the system is the chemical energy in the fuel, it implies that:

Heat rate $=$ Chemical energy of fuel/ Electrical energy out put

$=$ Total fuel flow (used) $\mathrm{x}$ fuel heating value/ power out put

Most power plants have a target or design heat rate (efficiency), for turning a steam turbine (e.g. natural gas 29.4 -

44.8 percent). It means that for every 100 units of primary heat energy that goes into the power plant, only $29.4-44.8$ units are converted to usable electrical energy (Ekejiuba ,2018a).

A $100 \%$ heat rate (efficiency) implies equal input and output: for $1 \mathrm{kWh}$ of output, the input must be $1 \mathrm{kWh}$ equivalent, that is thermal energy input of $1 \mathrm{kWh}=3.6 \mathrm{MJ}=3600 \mathrm{KJ}=3412 \mathrm{Btu}$.

This study assumed 30\%, therefore the heat rate become $3412 / 0.30 \mathrm{Btu} / \mathrm{kWh}=11,373.333 \mathrm{Btu} / \mathrm{kWh}$

The quantity of methane in flared stream designated for electricity generation is $4 \mathrm{MM}$ scfd which implies: $4,000,000 \mathrm{scf} / 24=166,666.666666 \mathrm{scf} / \mathrm{hr}$

Then Re- arranging the equation

Heat rate Btu/ kWh =Fuel Burned (Scf/ hr) x Heating Value (Btu/Scf)/ Power Output (kW), yields:

Power Output $(\mathrm{kW})=$ Fuel Burned (Scf/ hr) x Heating Value (Btu/ Scf)/ Heat rate Btu/kWh $=166,666.666666(\mathrm{scf} / \mathrm{hr}) \times 1000(\mathrm{Btu} / \mathrm{Scf}) / 11,373.333(\mathrm{Btu} / \mathrm{kWh})$

$=166,666,666.666(\mathrm{Btu} / \mathrm{hr}) / 11,373.333(\mathrm{Btu} / \mathrm{kWh})$

$=14,654.16 \mathrm{kWh} / \mathrm{h}$

$=14,654.16 \mathrm{~kW} \quad$ (approximately $15 \mathrm{MW}$ )

Conventionally, the rule of the thumb for power generation, for an industrial nation is about $1 \mathrm{MW}(1,000 \mathrm{~kW})$ for every thousand of the population (Vanguardngr.com, 2016). 


\subsection{Model for the Real-Time Synthetic Fuels Production Using 4mmscfd Fraction of the Methane}

\subsubsection{Overview of the GTL Monetization Option}

Most GTL technologies/ plants available from different licensors consists of the synthesis gas generation (manufacture), the methanol or FT synthesis facilities and the upgrading process. No matter the source material, once a mixture of $\mathrm{CO}$ and $\mathrm{H}_{2}$ is manufactured, with help from a catalyst, the syngas is transformed into waxy hydrocarbons, which in turn can be cracked into smaller, diesel- like fuel molecules (Ekejiuba, 2017b).

Syngas Conversion: There are two routes for the production of synfuels via syngas: the syngas is converted to, either hydrocarbon building blocks $\left(-\mathrm{CH}_{2}-\right)$ or hydrocarbon chain extension $\left(\mathrm{CH}_{2}\right) \mathrm{n}$, in the presence of a catalyst which produces different compound of hydrocarbon (liquid) via polymerization of the hydrocarbon building block.

The current three major processes that can convert synthesized natural gas to synthetic liquid fuels are:

- GTM- MTG Process: Gas to methanol (liquid) and further to Gasoline via di-methyl ether (DME

- STG + Process: Syngas to gasoline plus which builds on MTG via thermo chemical single loop- process.

- FT- GTL Process: Gas to synthetic fuel (liquid) diesel, gasoline, naphtha via fischer-tropsch synthesis.

4.3.1.1. Gas to-Methanol (GTM); Methanol- to-Gasoline (MTG) Process.

$2 \mathrm{H}_{2}(\mathrm{~g})+\mathrm{CO}(\mathrm{g}) \longrightarrow \mathrm{CH}_{3} \mathrm{OH}$

Synthesis gas Methanol

Mobil Process: Methanol polymerized over a zeolite catalyst to form alkanes via dimethyl ether (DME).

$2 \mathrm{CH}_{3} \mathrm{OH} \longrightarrow \mathrm{CH}_{3} \mathrm{OCH}_{3}+\mathrm{H}_{2} \mathrm{O}$

And further, the next reactions are:

$3 \mathrm{CH}_{3} \mathrm{OCH}_{3} \longrightarrow \mathrm{C}_{6} \mathrm{H}_{12}+3 \mathrm{H}_{2} \mathrm{O}$

In this process, hydrocarbon of five or more carbon atoms (gasoline) makes up over $80 \%$ of the fuel yield.

\subsubsection{SYNGas to Gasoline Plus ( STG +) Process}

The process is similar to the MTG technology, but coverts syngas directly into gasoline and jet fuel via a thermo chemical single -loop process (figure 6).

$\mathrm{CO}+\mathrm{H}_{2} \mathrm{CH}_{3} \mathrm{OH} \longrightarrow \mathrm{H}_{3} \mathrm{CH}_{3}$ hydrocarbons (mostlyC ${ }_{6}$ - $\mathrm{C}_{10}$ alkanes,aromatics)

Gasoline yield is 85 to $90 \%$ in this process.

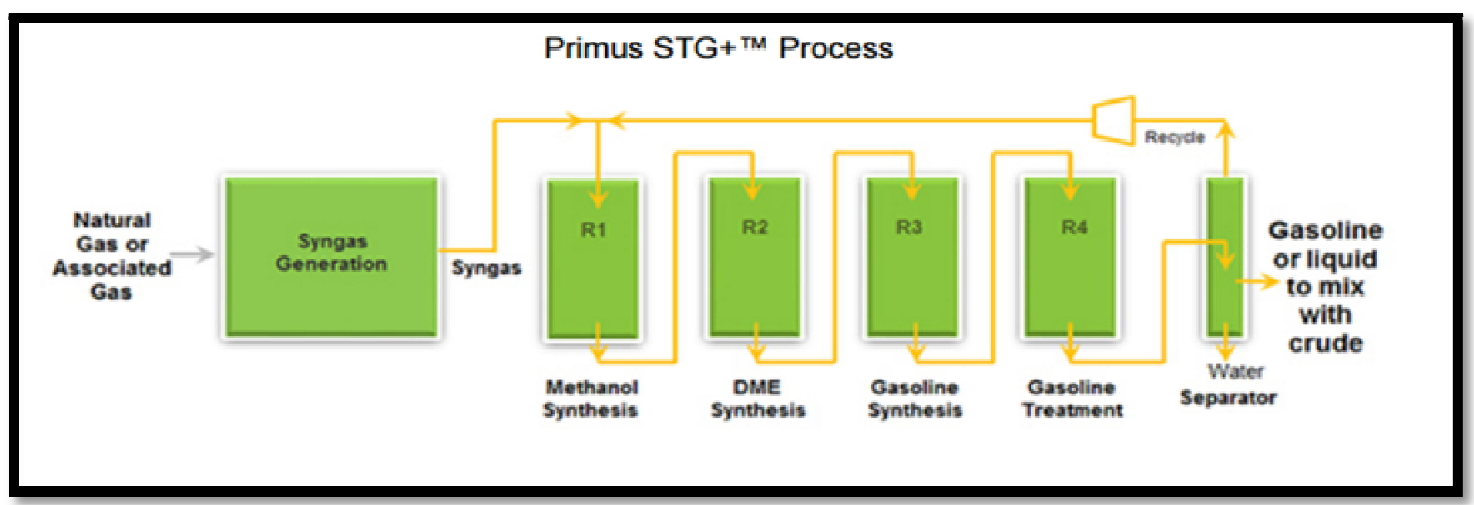

Figure 6: Syng as to Gasoline plus (Thermo-Chemical Single Loop- Process).

Source: Adapted From Images of Gas-to-Liquid Processes

\subsubsection{Fischer- Tropsch Synthesis}

Essentially the FT Synthesis is a bond forming exothermic reaction that actually converts syngas $\left(\mathrm{CO}\right.$ and $\left.\mathrm{H}_{2}\right)$ into hydrocarbon distribution such as liquids, methane, alkanes $\left(\mathrm{C}_{1}-\mathrm{C}_{100}\right)$, alkenes $(\mathrm{n} \geq 2)$, alcohols (oxygenated products) i.e. oxygen containing compounds, chemicals, waxes et cetera, with the help of selectivity catalysts, targeted at market demand. Usually, the temperature, pressure and catalyst determine the direction of the three chain growth reactions occurring at the same time with syngas.

The overall reactions which hides the mechanistic complexity can be described by chemical equations of the form.

- $\quad$ Formation of alkanes (paraffins)

$\mathrm{nCO}+(2 \mathrm{n}+1) \mathrm{H}_{2} \longrightarrow \mathrm{C}_{\mathrm{n}} \mathrm{H}_{2 \mathrm{n}+2}+\mathrm{nH}_{2} \mathrm{O}$ +heat.

- Formation of alkenes (Olefins)

$$
\mathrm{nCO}+2 \mathrm{nH}_{2} \longrightarrow \mathrm{C}_{\mathrm{n}} \mathrm{H}_{2 \mathrm{n}}+\mathrm{nH}_{2} \mathrm{O} \text { +heat }
$$

- Formation of oxygenates: alcohols or other oxygen containing compounds

$$
\mathrm{nCO}+2 \mathrm{nH}_{2} \longrightarrow \mathrm{H}_{2 \mathrm{n}+1} \mathrm{OH}+(\mathrm{n}-1)\left(\mathrm{H}_{2} \mathrm{O}\right) \text { theat }
$$




\subsubsection{Results for the GTL Products Quantity Evaluation}

The available feedstock is 4 MMsfd (Methane), and the selectivity of GTL processes, especially the FT process to $\mathrm{C}_{5+}$ products (i.e. liquid and wax) is $95 \%\left(\mathrm{nC}_{5+}\right)$, while the other $5 \%$ are gaseous $\mathrm{C}_{1}-\mathrm{C}_{4}$ products. Also, only $80 \%$ of the energy in the $95 \%$ syngas for conversion into $\mathrm{C}_{5+}$, is retained in the FT products, while the remaining $15 \%$ is released as reaction heat. With $80 \%$ selectivity for $\mathrm{nC}_{5+}$ it becomes $0.8 \mathrm{x} 4 \mathrm{MMscfd}=3,200,000 \mathrm{scfd}$

And applying the 10,000 scf conversion to approximately I barrel general rule, yields:

$3,200,000 \mathrm{scf} / 10,000 \mathrm{scf}=320$ barrels.

Which is equivalent to $42 \times 320=13,440$ US gallons or $160 \times 320=51,200$ liters.

4.4. Model for the Real-Time Nitrogenous Synthetic Fertilizer (Ammonia/Urea) Production Using 4mmscfd Fraction of the Methane

\subsubsection{Overview of Nitrogen Fertilizer Production}

The bulk hydrogen for industrial ammonia production can be generated from catalytic steam reforming of natural gas (methane) equation 2, otherwise known as steam methane reforming (SMR):

$$
\begin{aligned}
& \mathrm{CH}_{4}(\mathrm{~g})+\mathrm{H}_{2} \mathrm{O}(\mathrm{g}) \longleftrightarrow \mathrm{CO}(\mathrm{g})+3 \mathrm{H}_{2}(\mathrm{~g})+210 \mathrm{kjmol}^{-1} \\
& 1 \text { mole } 1 \text { mole } \quad 1 \text { mole } 3 \text { moles }
\end{aligned}
$$

Six basic steps are involved in plants that use catalytic steam reforming for synthetic ammonia production, figure 7: natural gas desulfurization, catalytic steam methane reforming, carbon monoxide (water-gas) shift, carbon dioxide removal (capture from SMR), methanation and ammonia/ urea synthesis.

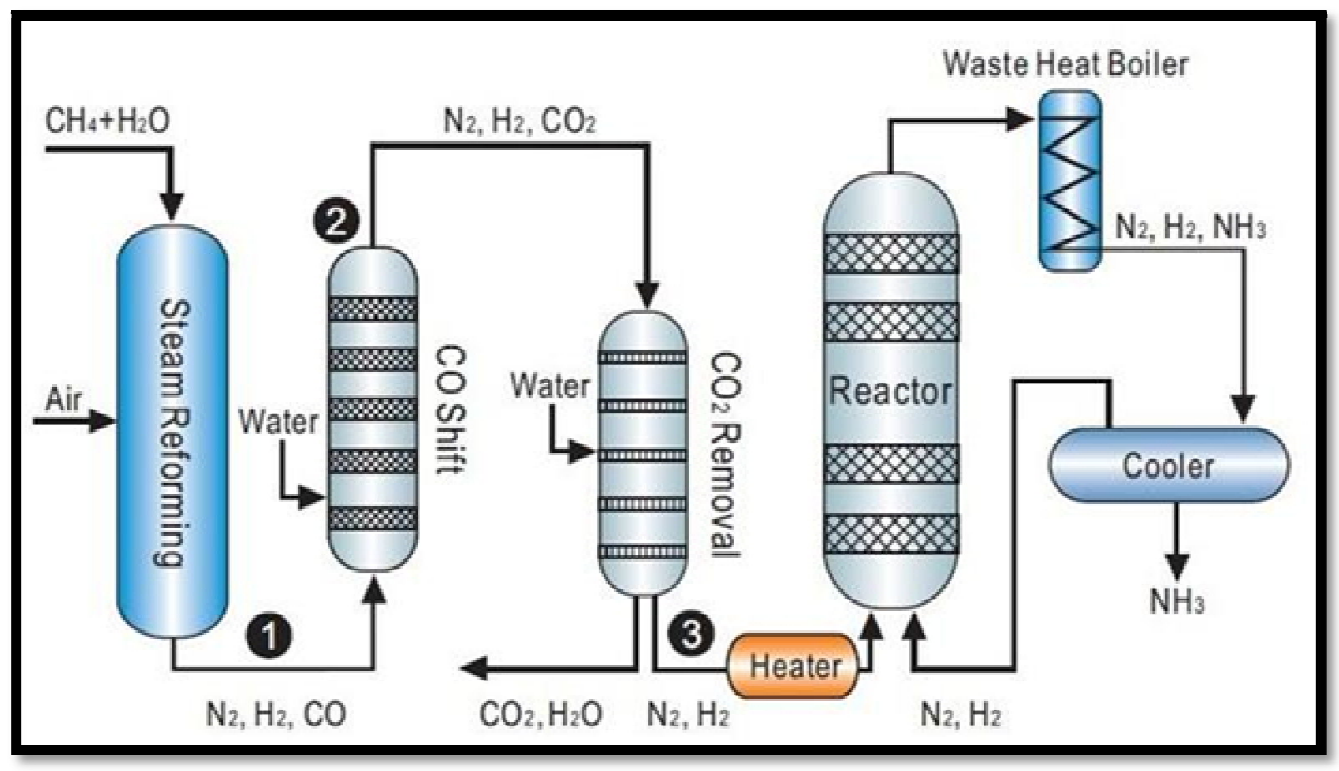

Figure 7: Ammonia Production from Natural Gas (Methane)

Source: Adapted From Images of Ammonia Process Units

The balanced equations for the Haber-Bosch process ammonia/ urea Synthesis are:

Ammonia Synthesis

$$
\begin{gathered}
\mathrm{N}_{2}+3 \mathrm{H}_{2} \\
1 \text { mole } \quad \longleftrightarrow \text { moles } \\
2 \text { 2moles }
\end{gathered}
$$

28.0 gram $\quad 6.0$ grams $\quad 34.0$ grams

Water-Shift:

$\mathrm{CO}(\mathrm{g})+\mathrm{H}_{2} \mathrm{O}(\mathrm{g}) \longleftrightarrow \mathrm{CO}_{2}(\mathrm{~g})+\mathrm{H}_{2}(\mathrm{~g})-42$ kjmol-1

Urea Synthesis:

$2 \mathrm{NH}_{3}(\mathrm{~g})+\mathrm{CO}_{2}(\mathrm{~g}) \longleftrightarrow\left(\mathrm{NH}_{2}\right)_{2} \mathrm{CO}(\mathrm{s})+\mathrm{H}_{2} \mathrm{O}(\mathrm{l})$

\subsubsection{Results of the Evaluation for the Urea Production Quantity}

Based on equation (2), each mole of methane will produce 3 moles of hydrogen required to react with 1 mole of nitrogen, to produce 2 moles of ammonia equation (1). In addition, each mole of the methane also produces 1 mole of carbon monoxide required for the water- shift reaction (equation 14), to produce 1 mole of carbon dioxide. Both products ammonia and carbon dioxide are synthesized to urea equation 15, thereby preventing carbon monoxide (potential green house gas) from entering the atmosphere. Applying the conversion from standard cubic feet (scf) to moles factor, $(1 \mathrm{scf}=$ 1.19804 moles), the 4MMscfd of methane, converts to 4,792,160 moles daily (i.e. 4,000,000 x 1.19804). Tables 4 to 7, 
Shows the reaction processes: Steam Methane Reforming; Ammonia Synthesis; Water-Gas-Shift and Urea Synthesis for estimating the overall quantities of ammonia/ urea (synthetic nitrogen fertilizer) obtainable from the fraction of flare stream (Ekejiuba, 2017c).

\begin{tabular}{|c|c|c|c|}
\hline $\begin{array}{l}\text { Molecular } \\
\text { FORMULA }\end{array}$ & $\begin{array}{l}\text { Number of } \\
\text { MOLES }\end{array}$ & $\begin{array}{c}\text { Atomic MASS PER } \\
\text { MOLE (GRAMS) }\end{array}$ & Overall MASS (GRAMS) \\
\hline CH4 \{methane\} & $4,792,160$ & 16 & $76,674,560$ \\
\hline $\mathrm{H} 2 \mathrm{O}$ \{water $\}$ & $4,792,160$ & 18 & $86,258,880$ \\
\hline $\begin{array}{l}\text { CO \{carbon } \\
\text { monoxide\} }\end{array}$ & $4,792,160$ & 28 & $134,180,480$ \\
\hline H2 \{hydrogen\} & $3(4,792,160)$ & 2 & $28,752,960$ \\
\hline $\begin{array}{l}\text { Molecular } \\
\text { formula }\end{array}$ & $\begin{array}{l}\text { Number of } \\
\text { moles }\end{array}$ & $\begin{array}{c}\text { Atomic mass per mole } \\
\text { (grams) }\end{array}$ & Overall mass (grams) \\
\hline N2 \{nitrogen\} & $4,792,160$ & 28 & $134,180,480$ \\
\hline H2 \{hydrogen\} & $3(4,792,160)$ & 2 & $28,752,960$ \\
\hline $\begin{array}{c}\mathrm{NH3} \\
\text { \{ammonia\} }\end{array}$ & $2(4,792,160)$ & 17 & $162,933,440$ \\
\hline
\end{tabular}

Table 4: Steam Methane Reforming

$\left\{\mathrm{CH}_{4}(\mathrm{~g})+\mathrm{H}_{2} \mathrm{O}(\mathrm{g}) \longleftrightarrow \mathrm{CO}(\mathrm{g})+3 \mathrm{H}_{2}\right\}$

Ammonia Synthesis

$\left\{\mathrm{N}_{2}+3 \mathrm{H}_{2} 2 \mathrm{NH}_{3}\right\}$

\begin{tabular}{|c|c|c|c|}
\hline Molecular Formula & Number Of Moles & Atomic Mass Per Mole (Grams) & Overall Mass (Grams) \\
\hline $\mathrm{CO}$ \{carbon monoxide $\}$ & $4,792,160$ & 28.0 & $134,180,480$ \\
\hline $\mathrm{H}_{2} \mathrm{O}$ \{water & $4,792,160$ & 18.0 & $86,258,880$ \\
\hline $\mathrm{CO}_{2}$ carbon dioxide $\}$ & $4,792,160$ & 44.0 & $210,855,040$ \\
\hline $\mathrm{H}_{2}$ hyydrogen & $4,792,160$ & 2.0 & $9,584,320$ \\
\hline
\end{tabular}

Table 5: Water-Gas Shift

$\left\{\mathrm{CO}(\mathrm{g})+\mathrm{H}_{2} \mathrm{O}(\mathrm{g}) \longleftrightarrow \mathrm{CO}_{2}(\mathrm{~g})+\mathrm{H}_{2}(\mathrm{~g})\right\}$

$\left\{2 \mathrm{NH}_{3}(\mathrm{~g})+\mathrm{CO}_{2}(\mathrm{~g}) \longleftrightarrow\left(\mathrm{NH}_{2}\right)_{2} \mathrm{CO}(\mathrm{s})+\mathrm{H}_{2} \mathrm{O}(\mathrm{l})\right\}$

\begin{tabular}{|c|c|c|c|}
\hline Molecular formula & Number of moles & $\begin{array}{l}\begin{array}{l}\text { Atomic mass } \\
\text { (grams) }\end{array} \\
\text { (ger mole }\end{array}$ & Overall mass (grams) \\
\hline $\mathrm{NH}_{3}\{\mathrm{ammonia}\}$ & $2(4,792,160)$ & 17.0 & $162,933,440$ \\
\hline $\mathrm{CO}_{2}$ \{carbon dioxide $\}$ & $4,792,160$ & 44.0 & $210,855,040$ \\
\hline$\left(\mathrm{NH}_{2}\right)_{2} \mathrm{CO}\{$ Urea $\}$ & $4,792,160$ & 60.0 & $287,529,600$ \\
\hline $\mathrm{H}_{2} \mathrm{O}$ \{water $\}$ & $4,792,160$ & 18.0 & $86,258,880$ \\
\hline
\end{tabular}

Table 6: Urea Synthesis

The expected final end products are:

- Urea $(287,529,600$ grams), from the urea synthesis reaction-table 7.

- Water, $\mathrm{H}_{2} \mathrm{O}(86,258,880$ grams), from the urea synthesis reaction-table 7 and

- Hydrogen (9,584,320 grams), from the water-gas-shift reaction-table 6.

Both $\mathrm{H}_{2} \mathrm{O}$ and $\mathrm{H}_{2}$ are recycled while urea 287,529.600 kg is bagged in $50 \mathrm{~kg}$ per bag

(i.e. $287,529.600 \mathrm{~kg} / 50 \mathrm{~kg}=5,750.592$ bags).

Thus, approximately 5,750 bags per day (synthetic nitrogen fertilizer), is obtained from the 4MMscfd methane fraction of the flow rate.

4.5. Model Results for the Real-Time Conversion of 2MMscfd fraction of the methane to either CNG, LNG or NGH

Associated stranded natural flared gas is measured in either standard cubic feet $\left(\mathrm{ft}^{3}\right)$ or cubic meters $\left(\mathrm{m}^{3}\right)$. When it is converted to LNG, CNG, or NGH, it is measured in mass units \{e.g. tons or million tons (MT) \}, and on reconversion to gas, it is sold by energy units (calorific value) commonly specified in dollars per British Thermal Unit (BTU), Joules (J) and kilocalories (kcal), figure 8 (Ekejiuba, 2018b). 


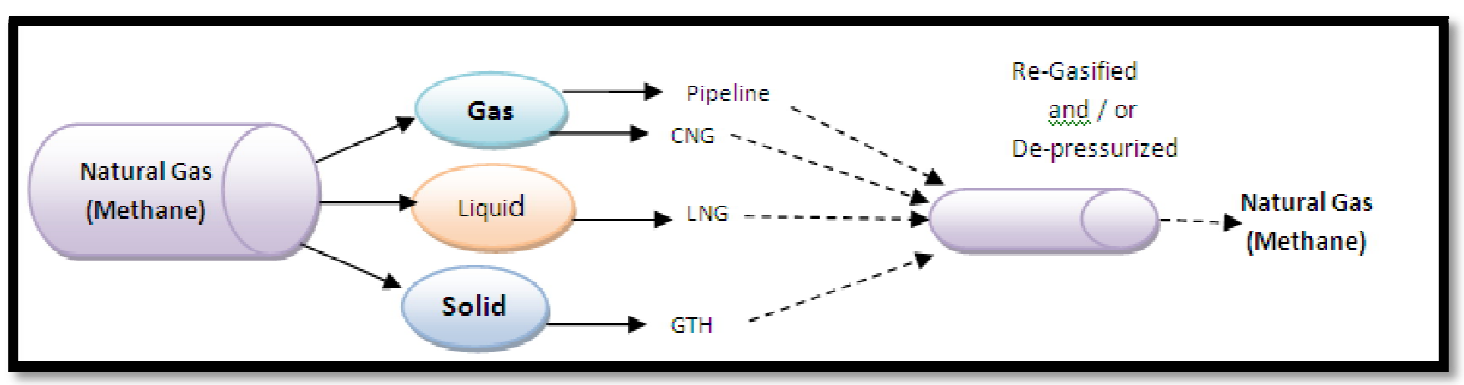

Figure 8: Modes of Delivering Natural Gas (Methane) in Gaseous Form to

Consumers: Pipelines and Via Conversion to CNG, LNG and GTH (NGH)

Source: Adapted from Ekejiuba, 2018b

Conversion from volume (cubic feet or cubic meters) to energy requires knowledge of the average calorific value i.e. heating value and the commonly use factor is 1,000 Btu/ scf.

The thermal efficiency for gas to gas transport systems are:

$\begin{array}{ll}\text { Pipeline } & >95 \% \\ \text { CNG } & 93+\% \\ \text { LNG } & 85 \text { to } 91 \% \\ \text { NGH } & 91 \%\end{array}$

Thermal efficiency is defined here as the ratio of heating value of the products to the heating value of the feed gas.

The quantity of flared methane designated for conversion is $2 \mathrm{MM}$ scfd, and the calorific value is:

$2,000,000$ scf $x 1,000 \mathrm{Btu} / \mathrm{scf} \quad=2,000,000,000 \mathrm{Btu}$ ( 2 billion Btu)

since $1 \mathrm{Btu}=1.055 \mathrm{kjoules}$, the kilojoules equivalent becomes

2 billion Btu x $1.055 \mathrm{~kJ} / \mathrm{Btu}=2.110$ billion $\mathrm{kJ}$.

Therefore, the available retail heat energy for each of the options becomes

CNG 2MMM Btu x $0.93=1,860,000,000$ Btu or (1.9623 billion kJ)

LNG 2MMM Btu $0.91=1,820,000,000$ Btu or ( 1.9201 billion kJ)

NGH 2 MMM Btu x $0.85=1,700,000,000$ Btu or (1.7935 billion kJ)

4.6. Model Results for the Real-Time Production of Petrochemical/ Chemical Using 1.708MM SCFD Fraction of the Methane

Natural gas (methane) is converted to petrochemical/ chemical via (a) chemical conversion to acetylene, methanol and refinery hydrogen, figure 9 (b) conversion to olefins (GTO) and further to polymers (GTP) figure 2. The basic olefins and polymers are ethylene, propylene, Butene-1, ethylene oxide, polypropylene, polyethylene, ethylene glycol, terephtalic acid, is opropanol, ethanol amines (Mono, Di, Tri), carbon black etc. The major olefin products are the ethylene and propylene (primary petrochemical products), while the major polymers are the polyethylene and polypropylene pellets. Polymers are the largest value-added products for the ultimate production of synthetic organic chemicals, which are in turn used in different commercial chemical industries to produce hundreds of finished specific chemicals for the medical, pharmaceutical (e.g. insect repellants, isopropanol, ethanolamines), agricultural (e.g. weed killers, insecticides/ pesticides), printing, plastics of all descriptions, cleaning agents (e.g. soaps and detergents), solvents, dyestuffs, greases waxes, drugs, fertilizer (ammonia), paints, synthetic textiles (e.g. artificial fibres) and synthetic rubbers, epoxy resins, flooring and insulating materials, and products as diverse as aspirin, luggage, boats, automobiles, aircraft, polyester clothes, adhesives, refrigerants, antifreeze, aerosols, alcohols, explosives, recording discs and tapes etc. (Ekejiuba, 2018c).

Currently, there are well over 2000 product made to individual formula by natural gas and allied petrochemical/ chemical plants. The limit in number and diversity of product and the extension of their application has by no means been reached. Through advanced technology and practical research, new products (constantly growing number of commercially manufactured products from natural gas/ petrochemical/ chemical plants) will continue to be added to the long list of those recovered or made from natural gas, with a continually widening range of consumer applications.

Despite the fact that these petrochemical products have already penetrated virtually all the material markets such as the agricultural, pharmaceutical, plastics and resins, building, automotive, electrical, synthetic fibres, synthetic rubber, cleaning agents etc.; an incipient attack on the most important of all 'the food markets' is indicated by the construction of plants in which protein will be made from hydrocarbons. 


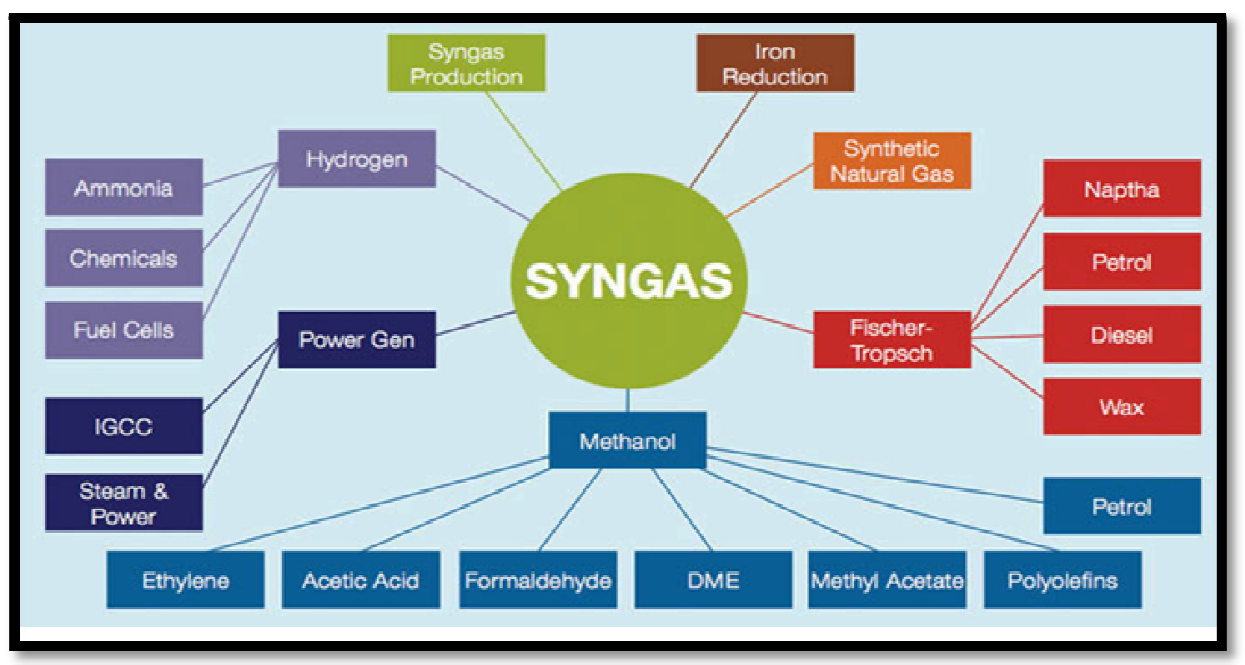

Figure 9: Schematic of Major Products from SYNGAs

Source: Adapted From Images of the Overall Gas to Liquid Process

\section{Conclusions}

Stranded natural gas refers to natural gas that is wasted or unused i.e., that has been discovered but is not, or will not be developed due to their location or the economy of getting the natural gas delivered to the market place. Therefore, we distinguish between the associated stranded (flared or vented) natural gas and the stranded natural gas reserve.

In Nigeria, flaring of associated stranded natural gas commenced in 1956 with the first successful well drilled at Oloibiri by Shell D'Arcy, present day Shell Petroleum Development Company (SPDC). Until 1984, the Country flared (ignited) or vented (unignited) virtually all the produced associated stranded natural gas, while between 1984 to 1999, the flaring reduced to $70 \%$. The introduction of monetization policy in 1999 further reduced, flaring from 70 per cent to between $43-52 \%$ in 2004, about where it still remains up-to-date. With the continuous flaring of about $50 \%$ of associated stranded natural gas in Nigeria, where the light crude contains substantial amount of the associated natural gas, the importance of an alternative to flaring can hardly be over emphasized.

Natural gas monetization options refers to the various processes and ways of converting the energy potentials of natural gas into monetary or utilization value through diverse value-added products, such as direct conversion to electric power ( gas to wire-GTW); conversion to liquids (gas to liquid-GTL i.e. synthetic fuels diesel ,gasoline, etc., methanol, dimethylether 'DME') ; conversion to olefins (gas to olefins-GTO) and further to polymers (gas to polymers-GTP) ; chemical conversion to acetylene, ammonia and urea (synthetic nitrogen fertilizer); production of liquefied petroleum gas (LPG); conversion to liquefied natural gas (LNG), compressed natural gas (CNG) and natural gas hydrates (NGH) for easy of transporting the natural gas to the desired destination etc. The design sizes and technologies available from different licensors for the various small-scale natural gas monetization options can be customized to process the entire quantity of natural gas from a flare line or the fractionrequired to yield specified quantity of the desired end-product.

Multiple or combined Real-Time monetization of the flared associated stranded natural gas involves the application of more than one of the natural gas small-scale monetization options on an individual flare line (stream), based on the flare stream volume and the various needs/desires of the host community, local government area, state and country, to accomplish zero flare, for example, an integrated power generation/nitrogen fertilizer production/ GTL/ petrochemical/ LNG or LPG.

The proposed Integrated Associated stranded Natural Gas Monetization Layout, figure 3 shows that the 20 MMscfd flow rate flare stream in this case study, is divided into 5 fractions after purification, for the daily generation of 15MW power electricity; production of 320 barrels (equivalent to 13,440 US gallons or 51,200 liters) of synfuels (gasoline, diesel etc.); production of 5,750 bags per day synthetic nitrogen fertilizer (ammonia/ urea); supply of 1,820,000,000 Btu of LNG and various petrochemicals/ chemicals such as ethylene, propylene, Butene-1, ethylene oxide, polypropylene, polyethylene, ethylene glycol, terephtalic acid, is opropanol, ethanol amines (Mono, Di, Tri), carbon black etc/ to produce hundreds of finished specific chemicals for various industries like the medical, pharmaceutical (e.g. insect repellants, is opropanol, ethanolamines), agricultural (e.g. weed killers, insecticides/ pesticides), printing (inks and dyes), plastics of all descriptions, cleaning agents (e.g. soaps and detergents), solvents, dyestuffs, greases waxes, drugs (e.g. aspirin), paints, synthetic textiles (e.g. artificial fibres), synthetic rubbers, epoxy resins, flooring and insulating materials and products as diverse as luggage, boats, automobiles, aircraft, polyester clothes, adhesives, refrigerants, antifreeze, aerosols, alcohols, explosives, recording discs and tapes etc.

\section{References}

i. Brown, W.H, Foote, C. S., Iverson, B.L 2005. Organic Chemistry, Fourth Edition, Thomson Books/ Coll Belmont, United State. P.97

ii. $\quad$ Croft Production System. NGL Recovery: Process and Equipment.

iii. $\quad$ https:/ / www.croftsystems.net/ oil-gas-blog/ ngl-recovery-process-and-equipment (accessed, 15:03: 18).

iv. Electricity-Wikipedia. https:en.wikipedia.org>wiki>Electricity (accessed, 26:05:17). 
v. Ekejiuba, A. I.B., 1990. Economic Viability of producing LPG and LNG from the Nigerian Flare Gas Stream: M.Eng. Dissertation, University of Port Harcourt, Nigeria.

vi. Ekejiuba, A. I. B., 2017a. Real-Time Monetization of the Flare Associated Stranded Natural Gas in Nigeria: Quantitative Analysis and Qualitative Values. The International Journal of Science \& Technology, Vol. 5 Issue 8, pp. 96, 99, 100.

vii. Ekejiuba, A. I. B., 2017b. Monetizing the Flared Associated Natural Gas in Real-Time Via Synthetic Fuels Production. The International Journal of Science \& Technology, Vol. 5 Issue 10, p. 162.

viii. Ekejiuba, A. I. B., 2017c. Evaluation of the Exact Production Quantity of Nitrogen Fertilizer in Real-Time from any Particular Associated Gas Flare Volume in Nigeria. The International Journal of Applied Science and Technology, Vol. 7. No. 3, pp. 97-98.

ix. Ekejiuba, A. I. B., 2018a. Flared Natural Gas Monetization in Real-Time Via Electric Power Generation. The International Journal of Science \& Technology, Vol. 6 Issue 1, p.144.

x. Ekejiuba, A.I.B., 2018b.Monetization of Remote Flared Natural Gas via Total Synthetic Conversion to Methane for Real-Time Production of Liquefied Natural Gas, Compressed Natural Gas or Natural Gas Hydrate. The International Journal of Science \& Technoledge. Volume 6 Issue 8: pp. 62,70.

xi. $\quad$ Ekejiuba, A.I.B.,2018c.Associated Stranded Natural Gas Monetized in Real-Time Via Conversion to Petrochemical and Other Useful End Products. International Journal of Innovative Research \& Development. Volume 7 Issue 7: 474-475. DOI No: 1.24940/ ijird/ 2018/ v7/i7/ JUL18126.

xii. 11. How Electricity is Generated -Energy Explained, Your Guide to Understand Energy-Energy Information Administration https:/ / www.eia.gov>energyexplained (accessed 27:05:17).

xiii. Ikoku, C. U., 1980. Natural Gas Engineering: A Systems Approach. Pennwell Books Tulsa, Oklahoma USA. pp. 20-21.

xiv. Images of Ammonia process units (accessed 7:09:17)

xv. Images of Gas-to-Liquid Processes (accessed 6:10:17)

xvi. Images of the overall gas to liquid process (accessed 9:10:17)

xvii. Katz, D.L. et al., 1959. Handbook of Natural Gas Engineering McGraw-Hill Book Company, New York. p.1.

xviii. Layfield, M., 2016. Creating Value from Flared Natural Gas. Journal of Petroleum Technology, 68/ 5.14-16.

xix. Malumfashi, G. I., 2008. Phase-Out of Gas Flaring in Nigeria by2008: The Prospects of A Multi-Win Project (Review of the Regulatory, Environmental and Socio-Economic Issues). Petroleum Training Journal. Vol. 4 No. 2. p. 124.

xx. $\quad$ Natural gas .org/ overview/ uses-electrical accessed 23:10:17

xxi. Ofoegbu, D.I., 2015. Gas Flaring in Nigeria: A Story for the Gods. The Nigerian Voice Newspaper. thenigerianvoice.com, (accessed 24:05:17).

xxii. Ogunade Kunle, 2016. Manufacturers import $80 \%$ of raw materials due to lack of ...energymixreport.com >Oil\&Gas〉 Downstream The Guardian reports(accessed 18: 07:18)

xxiii. Rao,V., 2016. Fugitive Gas and Flaring: Current and Future Realities. Journal of Petroleum Technology 68/4. 1619.

xxiv. $\quad$ Salvador, A., 2015. Natural Gas Liquids- AAPG Wiki Wiki.aapg.org>natural-gas-liquids (accessed, 19:05:17)

xxv. Shah, P; Durr, KBR. 2007. Monetizing Stranded Gas. In Lake, L.W., Warner Jr., H.R. 2007. Emerging and Peripheral Technologies, Petroleum Engineering Handbook, Volume VI, Society of Petroleum Engineers, Richardson, TX. USA. pp. VI-356.

xxvi. $\quad$ Sherman, S.J., Sherman,A.,1999. Essential Concepts of Chemistry. Houghton Mifflin Company. Boston. p 260.

xxvii. Timberlake, K.C., 2006. An Introduction to General, Organic and Biological Chemistry. Ninth Edition Person Benjamin Cummings. p 347.

xxviii. Uwandu, I., 2017. LPG Retail Pricing in Nigeria-Bussiness-Nigeria-Nairaland. www.nairaland.com/ 3819923/lpgretail-g-pricing-nigeria (accessed, 3:11:17).

xxix. 28. Vanguard, 2016. N25bn, 3000MW Power Lost to Gas Flaring. The Vanguard Newspaper.vanguardngr.com (accessed 24:05:17). 